\title{
SOCIAL CAPITAL MOBILIZATION STRATEGY TO SUSTAIN COMMUNITY ENTREPRENEURSHIP IN URBAN NEIGHBORHOOD
}

\author{
Prihadi Nugroho ${ }^{1}$ \\ Diterima: 13 Maret 2015 Disetujui: 06 April 2015
}

\begin{abstract}
Entrepreneurs in cities are prone to direct market change and urban growth in a country. Those who do not possess strong business network and strategic alliance are likely out of the game immediately. Building community entrepreneurship thus becomes critical to provide collective business network and learning, particularly for smaller entrepreneurs and new entrants, through the mobilization of social capital. This paper aims to examine how urban community institutionalizes the embedded stock of social capital in the neighborhood to cultivate sound entrepreneurial ambience parallel with the individual pursuit of profit maximization. The multiple strategies of incorporating traditional and informal inherited values into the contemporary dynamics of market and urban growth are quite successful to sustain the continuation of home-based industry in the neighborhood. The case study approach was undertaken to observe the re-emergence of local batik industry in Kampung Laweyan of Surakarta Municipality, Indonesia. The result demonstrates that social cohesion safeguarding is the key to encourage collective entrepreneurial skills development in the community albeit it does not affect much the building of stronger inter-firm cooperation.
\end{abstract}

Keywords: social capital mobilization, community entrepreneurship, urban neighborhood, local batik industry, Kampung Laweyan

\section{Introduction}

Entrepreneurs have long been admitted for their roles in promoting development. Through multiple channels of innovation and resource accumulation they modify value chain processes to produce goods and services for targeted markets (Søgaard, 2009). New firm creation provides a medium for these channeling processes involving staff recruitment and skill upgrading; thereby, innovation and new firm creation qualifies entrepreneurship definition (Guzmán\&Santos, 2009; Andersson, Curley \& Formica, 2010).Besides their economic contributions they also encourage social development through various ways of knowledge transfer, social capital mobilization and community empowerment. As entrepreneurs play dual functions as the owners and managers of their firm (Henderson, Low \&Weiler, 2007), the knowledge transfer occurs by utilizing family ties and social network instead of a rigid standard operational procedure as commonly applied in corporate firms. A loose" social contract" based on trust and sanction is more preferable in forming convenient working condition. This is possible because they mostly recruit staff

\footnotetext{
${ }^{1}$ Department of Urban and Regional Planning, Diponegoro University
} 
from family members, friends, and neighbors rather than using job vacancy advertisement or professional headhunter service. Such circumstance, therefore, makes them more vulnerable against changing environment due to their dependence to prevailing social structure and norms.

In response to the complexity of society and social systems entrepreneurs in cities deal with worse impacts of changing environment than their counterparts in villages. They are prone to direct market change and urban growth in a country. As cities perform as a market place for trading goods and services across the country - some major cities also serve as hubs for global trade - new product design and innovation supported by quality marketing and customer care services thus must be done continuously to sustain their business cycle in response to market trend. In addition, they must often deal with intense competition with harsh and unethical business practices which makes them adopting different strategies for maintaining market share. Moreover, they also have to anticipate the effects of urban growth. As urban economy grows, it consumes more lands for housing, public facilities and infrastructure, making the land/property prices higher for theurban entrepreneurs to spend for. They must also pay higher taxes, transportation costs and many other variable costs especially illegal levies. Despite benefiting from larger market expansion, they must offset additional intangible social costs such as traffic congestion, pollution and security into the unit production cost. Bearing all these burdens together, they struggle very hard for running the business. Therefore, those who do not possess strong business network and strategic alliance are likely out of the game immediately.

Building community entrepreneurship thus becomes critical to provide collective business network and learning, particularly for smaller entrepreneurs and new entrants, through the mobilization of social capital. So, why does community entrepreneurship matter? Given the fact that smaller entrepreneurs and new entrants have limited internal capacity and access to resources, they are unable to compete head-to-head with larger competitors. Due to the lower bargaining position, they cannot have fairer working contracts inside vertical business network where the network leader control sover all production routines and marketing. This makes the smaller entrepreneurs losing management control over their business structurally. In contrast, building horizontal collaboration may lead to stronger collective business network when participating entrepreneurs mutually share their competence and resources for strengthening market shares. Such alliance enables entrepreneurs in optimizing business strategy to achieve marketing objectives. However, it is inadequate to promote a more stable and long-lasting network if the collaboration conditions do not reinforce binding contracts among participating entrepreneurs. Regarding this matter community entrepreneurship takes place for establishing entrepreneurial collectivism within the adjacent neighborhood through social capital mobilization.

This paper aims to examine how urban community institutionalizes the embedded stock of social capital in the neighborhood to cultivate sound entrepreneurial ambience parallel with the individual pursuit of profit maximization. The discussion is organized into four sections. On the following section I will address a problem statement contextualizing the vulnerability of urban entrepreneurs in continuing business cycle in response to changing environment. The second part elaborates the importance of social network for urban entrepreneurs. Subsequently, I will discuss case study methodology that was used for this study, then followed by the case of the re-emergence of local batik industry in Kampung Laweyan of Surakarta Municipality in Indonesia to reveal how social capital being institutionalized by responsible urban community to continue the existence of local industry. At the final section I will present concluding remarks describing that stronger social cohesion in urban neighborhood indeed contributes directly to the creation of better 
community entrepreneurship, but it does not automatically lead to the improvement of collective business network.

\section{The Vulnerability of Urban Entrepreneurs in Response to Changing Environment}

What specifies urban entrepreneurs is associated with common characteristics of urban regions as a marketplace for exchanging resources and human activities from and to various places of a country. The classical view of development and planning theories has seen cities with their parasitic nature of collecting and redistributing resources from smaller towns and villages for the sake of urban development - a phenomenon known as an urbanbiased or polarized development (Douglass, 1998). Cities exploit resources from lower regions to support manufacturing and service industries by utilizing agricultural stocks of capital and labor then spreading out urban consumables throughout the country. However, such urban-led growth has been criticized for its overconfidence in inducing balanced development since the expansion of urban market is counterproductive to encourage endogenous rural development (Armstrong \& McGee, 1985). Meantime, the alternative views stressing on endogenous development and rural-urban interface, however, still necessitate the central role of urban regions. They suggest the transmission of selected urban functions to support agriculture and rural development parallel with the devolution of power to the local authority instead of urban elites. The so-called agropolitan paradigm reposition secondary cities or small towns to become a rural-based marketplace for providing required agricultural inputs as well as processing and marketing rural commodities to larger cities (Douglass, 1998). Therefore, their performance may counter balance polarized development by increasing the added value of agricultural outputs through rural industrialization, from which better income generation and living standards are likely to be attained.

Regardless of the distinction of market typology the cities perform in spatial system, their key role as a medium of resources exchange relatively similar to meet market demand. Responding to intensified globalization effects and the demise of territorial boundaries, many cities have transformed from marketing goods and services to marketing city-place itself. Consequently, cities are no longer static product of development but they feature dynamic process of development. In this sense, cities compete to create better places for living, working and amenities. New city image building brings upfront a variety of business opportunities and new investments in urban industry involving broader use of advanced information technology. Value chain process is not merely designed for producing quality goods and services in compliance with international standards, for example, rather there is a growing attention from mayors and city managers for transforming cityscape formation to represent a unique local character (see $\mathrm{Xu} \& \mathrm{Yeh}$, 2005). It has come up with inexorable innovations in such a way that producing and marketing commodities put forward consumer taste and entire market demand into capricious demand-supply cycle. In line with the post-Fordism movement and global pressure suggesting for green economy agenda, urban market changes to reinforce the adoption of general rules of environmental protection into urban sectors. As a result,the groups of urban industrialists, investors and entrepreneurs have been exerted to focus more on human and social capital development instead of exploiting natural resources and physical capital for enlarging urban growth.

Following greater concern on urban competitiveness and green economy promotion, urban entrepreneurs are facing volatile conditions stemmed from both domestic and global pressures against which they must modify the modes of production and marketing responsively to maintain business cycle. The urban market changes, so does the forces beyond. In addition, policies and regulations are made by the leaders and policymakers who are mostly settling in urban dormitories. In spite of collecting broader access to 
abundant resources for business continuation, those urban entrepreneurs, particularly who do not have close connections with the decision makers, are susceptible to unfavorable policy process and its impacts to market competition. Simply the urban agencies create institutional obstacles because of which they calculate the costs of additional risks and potential losses of inefficient business cycle.

Compared to their counterparts in villages, the urban entrepreneurs must compensate those costs even before they start doing business. Even though having more opportunities, they must struggle with more risks. In doing so, they utilize social network for reducing transaction costs and anticipating uncertainties rather than solely relying on family kinship. Incorporating non-tradable variables like primordial ties into the business routine, however, remains important to minimize potential losses and maximize profits in market competition. The following section will discuss how social network could be advantageous for the urban entrepreneurs.

\section{The Importance of Social Network for Urban Entrepreneurs}

According to Lin (2001), the foundation of social network actually rests on the prevailing social structure and action. Social structure embraces power hierarchy and distribution in a society. Resources possession and exchange are transmitted through multiple relations vertically and horizontally. This process does not occur freely, meaning that actors holding higher position and greater possession of resources tend to manipulate the existing structure for actualizing their self-interests. The action element defines typical social exchanges between actors involving the flows of their resources and motives. The end of this action is the expected returns of well-being from each party advantageous for improving their living standards.

Effective social network requires trust and sanction to govern participating actors' obedience towards determined rules and regulations. This is necessary to ascertain the fulfilment of shared goals and actions of the participating actors to satisfy their self-interests with minimum harmful impacts to others and the rest of society. Assuming that market imperfection is the most common situation of societies everywhere including in the Western countries, information of resources tends to be polarised into the owners of plenty resources and ruling parties. Asymmetric information leads actors to find alternative ways for accessing required information even though it will cost them more. Another assumption is that the participating actors in the network are rational players in the decision making process, so that they are aware of the golden rule that "the winner takes it all". This means that the transaction costs represents trade-offs between the buyers ("the trustors") and the sellers ("the trustees") in demand-supply law (Buskens, 2002). Therefore, network governance codifies certain reward-and-punishment mechanism to assure the reinforcement of " $3 \mathrm{C}$ principles" - competition, cooperation and coordination - within the existing social network.

The existing social networkisuseful to provide the urban entrepreneurs scaffolding for building up their business. At initial stage, social network informs new entrants the possibilities of a variety of businesses, market size, value chain process, access to capitals and institutional framework available to run preferred business. Initial recognition towards these factors is as much important as business intuition that the new entrants must have for the long-term business continuation. In other words, risk-taking and profit-maximizing mentality should be continuously adjusted to adapt the overall business environment, including its prospects and obstacles, in which the entrepreneur sadhere most of times for. Close friends and family relatives are influential actors who predominantly support the new entrants at this stage. Often they choose to initiate or continue family business to seek for a comfort zone for learning many aspects of business strategy and marketing. Not 
surprisingly, they are benefited from such a bonding social capital to collect basic business knowledge, financial support, technical advancement and more importantly a seedbed of entrepreneurial skills upgrading as well as business growth. As the market size is relatively small and limited, supplier-buyer relations are built upon thick trust for lubricating transactions. Non-collateral loan, late payment, cross-selling and mouth-to-mouth marketing are some common practices to maintain business relations and consumer's loyalty. Therefore, the investment infinancial transactions and social relations are higher than the potential profits obtained.

When the business steps up to the next levels of maturity, the typical social network required is not solely being clung into primordial kinship but develops in line with its growth. The scope and types of social network may includea wide array of participating actors ranging from business partners to government agencies and external service providers - the kind of network called bridging social capital. Occasionally, the urban entrepreneurs need business partners for market positioning purpose. Business partners may provide additional investment in physical capital, labour, technology and marketing network. The role of government agencies is necessary to disseminating broader market access, providing soft loans and practical trainings and reinforcing business regulation and industrial standardization. As for the external service providers, their contribution is identifiable during business development and production capacity upgrading, in which research and development institutions responsible for. Banks and other financial institutions contribute in strengthening the entrepreneurs' financial capacity to expand business. Brokers or middlemen support them through multiple ways to connect the urban entrepreneurs with all those actors aforementioned. Since the participating actors in the social network are so vary, contractual agreements are required to reinforce thickened trust. To some extent, sometimes, the role of brokers is more powerful than the other actors in the network due to their flexibility in intermediating both dense networks and structural holes. While the dense networks encourage direct and repetitive contacts between actors to build thickened trust and more efficient transaction costs, the structural holes suggest intermediate functions performed by the brokers to result in similar objectives (Burt, 2001; Buskens, 2002). Since the urban entrepreneurs attempt to put forth the brand image of their business at this stage, their role is useful to quality service improvement and market segment positioning by informing the producers about change in consumer taste and the entire market competition.

Turning to the advanced level of business growth, the urban entrepreneurs are likely to expand the core business through product innovation and diversification. Some successful entrepreneurs could have independent research and development division and in-house training facility for ensuring never-ending research to improve their branded goods and service. Alternatively, they could hire expert consultant in order to maintain business growth as well as market share. In contrast, those who have limited access to human capital investment need much support from the external agencies for continuing the business. Inevitably, social network contributes differently at this stage. As for the successful group, it helps to incubate business alliance with the competitors for withholding certain market dominance. It promotes each entrepreneur inconforming business portfolios at minimum cost, thanks to fast circulation of entrepreneur's good (and bad) reputation shared within and between the existing networks. Nowadays, all information about entrepreneur's success and misconduct are accessible through social media and many types of information technology with exception to (lagging) rural and remote areas. In different case, social network is useful to accelerate innovation and knowledge transfer, particularly for smaller entrepreneurs. It reproduces technological innovation through imitation and modification, and the most favored modes of transfer are direct apprenticeship and spread of words rather than formal trainings. However, such social 
capital institutionalization greatly depends on voluntary deed of the joining entrepreneurs in the network. As a consequence, the persistence of such cooperation is flexible to change depending on the common self-interests they have shared already. Yet, many successful entrepreneurs still cultivate primordial ties as the main source of social networking for safeguarding them from undesired manipulation of their partners, alliance members and competitors.

Clearly, the social network evolves along the pace of business development. Primordial kinship plays the first source of the network in providing initial resources for business start-up. When the business grows, the types and scope of social network required enlarge involving more participating actors, but it does not necessarily get rid of the importance of primordial ties. The urban entrepreneurs are benefited from the complexity of numerous social networks in urban neighborhood. On the other hand, they are prone to unstable support of the existing networks due to high level of competition in urban market. Thus, primordial kinship may overcome the network deficiencies of bridging social capital with the external agencies.

\section{Case Study Methodology}

Case study approach was used in this study to understand the re-emergence of local batik industry in Kampung Laweyan of Surakarta Municipality, Indonesia. According to Creswell (2007) and Yin (2009), case study approach is useful to explore how things work in current situation where the availability of past evidence and the control of researcher are limited or absent. It focuses on phenomena in specific boundaries in order to result in analytic rather than statistical generalizations. As the case is highly contextualized into particular localities, the findings are expected to reveal depth exploration on real-life events. Triangulation method is therefore necessary to provide an iterative looping analysis to examine multiple sources of evidence (Hancock \&Algozzine, 2006; Yin, 2009; Woodside, 2010). The use of this method for data collection and analysis is advantageous to check data similarities and consistencies in order to prevent the findings from potential biases (Patton, 2002; Given, 2008). At the end, the findings may disclose not only alternative explanations about the working of phenomena, but also their breadth and depth of meanings (Lewis \& Ritchie, 2003; Stake, 2010).

The unit of analysis was batik cluster organization in Kampung Laweyan, consisting of community-based organization, individual batik firm and the adjacent neighborhood society. Kampung Laweyan was an urban settlement complex in Surakarta Municipality with population size of 1,791 inhabitants based on 2012 data (Solo Kota Kita, 2013). It was famously recognized with the home-based batik industry covering 88 batik firms (Nugroho, 2014). The data collection was completed in eight months from November 2011 to July 2012, and the analysis was done by December 2013. Primary data sources were collected through a series of interviews and questionnaires involving local batik entrepreneurs, prominent leaders and activists and various government agencies, i.e. Badan Perencanaan Pembangunan Daerah (BAPPEDA) or Local Development Planning Authority, Dinas Perindustriandan Perdagangan(DISPERINDAG) or Local Agency for Industry and Trade, Dinas Koperasi, Usaha Mikro, Kecil, dan Menengah(DISKOP-UMKM) or Local Agency for Cooperative, Micro, Small, and Medium Business, Dinas Pariwisata (DISPARTA) or Local Agency for Tourism, and a quasi-government agency called Forum for Economic Development and Employment Promotion (FEDEP). There were17 persons involved in the interview session and 21 persons in the questionnaire survey. Direct observations and secondary data collection were also done for triangulation purpose by taking up field notes, videotaping, photo-taking, statistical reports, public documents, previous studies and media publications (Nugroho, 2014). 


\section{Community Entrepreneurship in Urban Neighborhood: A Case of KampungLaweyan in Surakarta Municipality, Indonesia}

Despite having easier access to numerous social networks, still many urban entrepreneurs are unable to utilize them easily. Minimum experience and capability in running business could be the major cause. Another cause could be associated with the prevailing social structure where some urban entrepreneurs must cope with institutional obstacles to access linking social capital. Whilst the former relates to the capacity of individual entrepreneurial skills, the latter is embedded within the structure of community organizations. If the individual entrepreneurial skills are upgradable through a series of trainings, the structure of community organizations is a sum of social dynamics constituting power hierarchy and relations in a society.

The urban neighborhood in Kampung Laweyan of Surakarta Municipality perpetuatedthis situation well during the re-emergence of local batik industry in the early 2000s. Historically, the initial establishment of community entrepreneurship in KampungLaweyan was triggered by abundant supply of cotton plants around. From the sixteenth to the early twentieth century, there were large cotton plantation areas stretched along Bengawan Solo River, including the river banks of KampungLaweyan settlement (see Lombard, 2008). To respond the domestic market of textile production, the local residents, particularly the wives of cotton farmers, initiated weaving industry at homes. They produced woven fabrics for personal use, and later also did batik fabrics and clothing in response to growing demand from the royal family and local market.It was not surprising since their location was close to the capital of ancient Pajang Monarchy (1568-1586), from which the batik making skills of the local entrepreneurs had been got enriched. For the Javanese women in the old times, traditional weaving and batik making skills were inherited across generations. Not surprisingly, when it came for running own business they had already equipped with basic knowledge of textile production. The courage to start-up family business was triggered by two factors: income generation and market demand. As the primary income earned from cotton harvesting was insufficient to meet household needs, the farmers' wives turned to utilize their inherited skills for collecting additional income. Meantime, the labor shift in producing woven and batik fabrics from domestic to market purposewas correlated with the increase of textile demand locally (Nugroho, 2014).Therefore, the entrepreneurial skills of the KampungLaweyan's batik entrepreneurs were resulted from combined natural talent inheritance and reinforcing market demand.

The rise of a group of female entrepreneurs in KampungLaweyan- who later named by MbokMase - transformed the local batik industry from a side job into the primary source of income generation. Within the MbokMase system the female entrepreneurs owned and controlled the overall family business where the husbands were responsible for production control only. They did direct technical supervision as well as transfer of knowledge and innovation through a series of confidential in-house apprenticeship programs and skill upgrading trainings either for the preferred business successors or batik workers. This approach was commonly applied for preventing product imitation. Moreover, family bonding inclusion was practiced to protect the skillful batik workers from being hijacked by the competitors.Regarding product marketing and distribution, they were accustomed to utilize individual business networking and family relationship in order to establish consumer loyalty and market segment (Nugroho, 2014).

Featured with strong and closed individual business network, the local batik entrepreneurs built a typical exclusive batik production center. Since the late 1800s KampungLaweyan was broadly known as a closed and elite urban community. The social structure was formed by the dominating role of small number of juragan batik (large batik 
master). Inevitably, the economic possession and success in business activity, as shown by their large fortress-like houses, fancy automobiles and business properties, determined social divide within the KampungLaweyan community. The successful juragan batikwhowere placed at the top rank of social structure enabled them to dominatebatik trading circulation in respective urban market as well as social and physical development in the KampungLaweyanneighborhood. On the contrary, some smaller batik entrepreneurs attempted to maintain close connections with them as subcontractors to follow their success while the rest managed independent business development path for accessing lower market segment (Nugroho, 2014). However, since their business and social relations were built upon strong individualism, it rather created a peculiar social harmonyresulted from asymmetric social structure. The small elite group directed the decision-making process to determine how the local community should be.In this sense, the men domination within the prevailing social structure was under the shades of their women's control in the family business. Such circumstance lasted until the late 1990s following the gradual decline of the local batik industry's golden era since 1970s.

When the re-emergence of the local batik industry was publicly announced in 2004, many changes appear to introduce "a new face" of the KampungLaweyanneighborhood. Currently, both the business activity and society are more opened to the general public. Many home-based batik galleries are built in front of the main residence throughout the neighborhood in addition to sustained conventional marketing and distribution channels to the local (and national) markets and private buyers. The typical strong individual business network develops to stimulate limited number and scale of business alliances by continuing subcontracting and family kinship patterns. The local residents are now more opened and welcome visitors and new investors in doing business in KampungLaweyan. On the other hand, the old institutional framework seemspersisting, i.e. that the powerful elite group remains taking control over business and social relations. Currently, it consists of the large batik business successors and prominent senior citizens. Even though the initiative was mobilized by the younger generations who established a community-based organization called Forum PengembanganKampung Batik Laweyan (FPKBL) or Kampung Batik Laweyan Development Forum, the decisions to further the local batik industry - often it is also related to social and physical development programs in the KampungLaweyanneighborhood-must be firstly consulted and under supervision by the elite group (Nugroho, 2014). Not surprisingly, many initiatives for promoting collective business enlargement such as communal batik gallery, batik training center and industrial liquid waste treatment facility fail to exist due to stubborn attitude and strong individualistic behavior of the local entrepreneurs. As a result, the so-called inherited social harmony remains the major character of entrepreneurial ambience in the Kampung Laweyan's batik industry.

In response to such annoying social inheritance, the FPKBL adapts multiple social capital mobilization strategies to foster community entrepreneurship. Despite relying on the prevailing social structure, the FPKBL encourages joint marketing exhibition regularly to gather the old business players and new entrants for promoting new products. This event is useful to stimulate shared business knowledge and industrial innovation when inter-firm cooperation is nearly absent. The second approach is promoting kampong revitalization program to improve the physical condition of the entire neighborhood. With technical and financial support from various government agencies and donors, the FPKBL transforms the residential complex of Kampung Laweyan to become a prominent cultural heritage site in Surakarta. Third, the continuous promotion of Kampung Laweyan as a tourism destination site attracts visitors to better recognize its new image. Not only potential buyers are targeted to visit, but also school pupils, researchers and the public can enjoy learning batik making trainings in several local firms. Fourth, performing intermediate function to 
overcome social dispute. In this sense, the FPKBL facilitates conflicting parties to find the best solutions for all without intervening each entrepreneur's individual business undertakings (Nugroho, 2014).

Clearly, the abovementioned efforts led by the FPKBL demonstrate how the urban community manages potential bridging social capital by inviting external parties to interact with the local entrepreneurs and residents. Alternatively, it encourages them to get broader connection with external agencies. The underlying message of these multiple strategies is threefold: first, how to promote entire batik industry and neighborhood outwards as a single entity in order to counter-balance the persistence of strong individual business network; second, how to facilitate progressive collective actions without disrupting the prevailing hegemonic social structure to maintain the so-called social harmony; and third, how to create prospective events to lure broadening exposure for the local entrepreneurs' business activities entirely in order encourage their broader participation to support the FPKBL's programs. These efforts are quite successful to reduce the deteriorating effects of the dominating bonding and linking social capital accumulated in the circle of elite group. In short term, the FPKBL which represents the urban community organizationis able to foster community entrepreneurship. In long-term, the sustainable participation from the local entrepreneurs and residents should be maintained carefully to cultivate sound business climate and entrepreneurial ambience in the Kampung Laweyan neighborhood.

\section{Conclusions}

I began this article by addressing how the urban community institutionalizes the embedded stock of social capital in cultivating sound entrepreneurial ambience in the urban neighborhood. The findings taken from the KampungLaweyan case shed the light on that the persistence of primordial ties remain strong in the local home-based industry complex. One plausible reason is associated with the nature of batik industry as a family business which is inherited over generations. This leads to continuing transfers of batik making skills as well as individual business network. Another reason relates to typical Javanese culture suggesting for the so-called social harmony within a hierarchical social structure. It heightens proper appreciation towards the elderly groups and those who are holding higher position in a society. Therefore, direct accusation and refusal against them in the prevailing social order are considerably impolite manner.

Living in the urban neighborhood under such socio-cultural setting to some extent creates complicated institutional framework that the local entrepreneurs and residents must be familiar with for continuing their business and daily life. The case of Kampung Laweyan provides a new insight of social capital mobilization strategy where the counterbalance against strong primordial ties - in this case is shown by the strong individual (family-based) business network-could be done without dismantling their contribution. In this sense, incorporating traditional and informal inherited values is necessary to continue the local industry. The mobilization of bridging social capital with external parties is useful to redirect the persistence of bonding (and linking) social capital in response to the prevailing hierarchical social order. However, further research is required to examine the appropriateness of this approach for the long-term. Special attention should be placed on whether the broader intensified participation to support the bottom-up initiatives led by the local community-based organization could be maintained longer or it just a kind of one-off transaction to obtain plentiful economic externalities resulted from such collective actions. 


\section{Acknowledgements}

I would like to thank to the Directorate General of Higher Education (DGHE) of the Ministry of Education and Culture of the Republic of Indonesia who has supported the funding of my $\mathrm{PhD}$ research, from which this article was partially extracted. When doing the research I obtained valuable support from fieldwork team consisting of Ms. Syarifah Dina Fajriah, Mr. Terbit Nawolo Jati, Ms. Hasanatun Nisa Thamrin and Ms. Rizqa Hidayani. Special thanks is rewarded to Mr. Alpha Febela Priyatmono and Mr. Arif Budiman Efendi - both are the FPKBL board members - who provided substantiated information access to overwhelmingly comprehend the Kampung Laweyan society. Also, I would like to express my gratitude to participating interviewees, respondents and the entire society of Kampung Laweyan for their genuine welcome and shared knowledge during the data collection and analysis.

\section{References}

Andersson, T., Curley, M. G. \& Formica, P. (2010).Knowledge-driven entrepreneurship: The key to social and economic transformation. New York: Springer.

Armstrong, W. \& McGee, T.G. (1985).Theatres of accumulation. London: Methuen.

Douglass, M. (1998). A regional network strategy for reciprocal rural-urban linkages: An agenda for policy research with reference to Indonesia. Third World Planning Review, 20(1), 1-31.

Burt, R.S. (2001). Structural holes versus network closure as social capital.In N. Lin, K. Cook \& R.S. Burt (Eds.), Social capital: Theory and research (pp. 31-56). New York: Aldine De Gruyter.

Buskens, V. (2002).Social network and trust. Dordrecht: Kluwer Academic Publishers.

Creswell, J.W. (2007). Qualitative inquiry and research design: Choosing among five approaches. Second Edition. Thousand Oaks: Sage Publications.

Given, L.M. (2008).The Sage encyclopedia of qualitative research methods: Volume 1 \& 2. Thousand Oaks: Sage Publications, Inc.

Guzmán, J. \& Santos, F. J. (2009).Entrepreneurial structure from a regional perspective. In M. Galindo, J. Guzman, \& D. Ribeiro (Eds.), Entrepreneurship and business: A regional perspective (pp. 52-74). Berlin: Springer-Verlag.

Hancock, D.R. \&Algozzine, B. (2006).Doing case study research: A practical guide for beginning researchers. New York: Teachers College, Columbia University.

Henderson, J., Low, S. A., \&Weiler, S. (2007). The drivers of regional entrepreneurship in rural and metro areas.In N. Walzer (Ed.), Entrepreneurship and local economic development (pp. 81-102). Plymouth: Lexington Books.

Lewis, J. \& Ritchie, J. (2003).Generalising from qualitative research. In J. Lewis and J. Ritchie (Eds.), Qualitative research practice: A guide for social science students and researchers (pp. 263-286). Thousand Oaks: Sage Publications, Inc.

Lin, N. (2001). Building a network theory of social capital. In N. Lin, K. Cook \& R.S. Burt (Eds.), Social capital: Theory and research (pp. 3-30). New York: Aldine De Gruyter.

Lombard, D. (2008). Nusa Jawa: SilangBudayakajiansejarahterpadu, Buku III: Warisankerajaankerajaankonsentris. Jakarta: PT. GramediaPustakaUtama in collaboration with Forum Jakarta - Paris and Écolefrançaised'Extrême-Orient.

Nugroho, P. (2014). The role of local institutions in industrial cluster development in Indonesia: The cases of Javanese batik clusters in KampungLaweyan, KampungKauman and Lasem Area (Unpublished doctoral thesis), TechnischeUniversitat Dortmund, Germany.

Patton, M.Q. (2002). Qualitative research and evaluation methods.Third Edition. Thousand Oaks: Sage Publications, Inc.

Søgaard, V. (2009). Entrepreneurship and growth: The need to combine micro and macro perspectives. In M. Galindo, J. Guzman, \& D. Ribeiro (Eds.), Entrepreneurship and business: A regional perspective (pp. 75100). Berlin: Springer-Verlag.

Solo Kota Kita (2013).Laweyan. Retrieved from Solo Kota Kita website: http://solokotakita.org/neighborhood/laweyan-2/ 
Stake, R.E. (2010).Qualitative research: Studying how things work. New York: The Guilford Press.

Woodside, A.G. (2010). Case study research: Theory, methods, practice. Bingley, United Kingdom: Emerald Group Publishing Limited.

Xu, J. \&Yeh, A.G.O. (2005). City repositioning and competitiveness building in regional development: New development strategies in Guangzhou, China. International Journal of Urban and Regional Research, 292, 283-308.

Yin, R.B. (2009).Case study research: Design and methods. Fourth Edition. Thousand Oaks: Sage Publications. 